\title{
BOYS' AND GIRLS' CYBERBULLYING BEHAVIOURS IN PORTUGAL: EXPLORING SEX DIFFERENCES IN ADOLESCENCE USING GENDER LENSES ${ }^{1}$
}

\author{
Cristina C. Vieira*, Armanda Matos*, João Amado*, \\ Isabel Freire ${ }^{* *}$ and Ana Margarida Veiga Simão***
}

\begin{abstract}
In this paper, we explore the differences in the responses of adolescent boys and girls, as victims or perpetrators of cyberbullying, in a Portuguese study involving 1683 boys and 1837 girls from the $6^{\text {th }}, 8^{\text {th }}$ and $11^{\text {th }}$ years in 23 schools. More girls were cybervictims and more males were cyberaggressors. In both sexes, having already been a perpetrator was positively associated with having already been a victim. The breakdown of friendships and social rejection were the reasons most frequently cited by girls for experiencing and engaging in cyberbullying and they were more able than boys to disclose the motives and emotions involved in cyberacts. The implications are discussed, taking gender socialization and the characteristics of this stage of development into consideration.
\end{abstract}

Keywords: cyberbullying, differences between boyas and girls, adlescence, peer interaction analysis, gender stereotypes.

\section{Resumo}

Comportamentos de cyberbullying em rapazes e raparigas em Portugal: explorando diferenças entre os sexos na adolescência através das lentes de género

$\mathrm{O}$ artigo explora diferenças entre as respostas de rapazes e raparigas adolescentes, quer como vítimas, quer como perpetradores/as de cyberbulling, num estudo português com 1683 alunos e 1837 alunas do $6 .^{\circ}$, 8. $^{\circ}$ e $11 .^{\circ}$ ano de 23 escolas. Elas tenderam mais a ser vítimas e eles a serem agressores. Em ambos os sexos, ter sido já perpetrador mostrou-se positivamente associado ao já ter sido vítima. A quebra de amizades e a rejeição social foram as razões mais apontadas por elas para explicar as experiências quer de vitimização, quer de perpetração de cyberbullying, sendo que foram mais capazes do que eles de indicar as emoções e os motivos envolvidos. São discutidas implicações, levando em conta a socialização de género e as caraterísticas desta etapa do desenvolvimento.

Palavras-chave: cyberbullying, diferenças entre os sexos, adolescência, estilos de interação entre pares, estereótipos de género.

* Faculty of Psychology and Educational Sciences, University of Coimbra, 3000-115 Coimbra, Portugal.

E-mail: vieira@fpce.uc.pt

Postal Address: Rua do Colégio Novo, 3000-115 Coimbra, Portugal.

** Institute of Education, University of Lisbon, 1649-013 Lisboa, Portugal.

*** Faculty of Psychology, University of Lisbon, Research Centre for Psychological Science (CICPSI), 1649-013 Lisboa, Portugal.

1 This paper was prepared using data from the project Cyberbullying - A diagnosis of the situation in Portugal, which was coordinated by the third author and funded by the Portuguese Foundation for Science and Technology (PTDC/CPE-CED/108563/2008) between 2011 and 2013. 


\section{Resumen}

Comportamientos de cyberbullying en los niños y niñas en Portugal: exploración de las diferencias entre los sexos en la adolescencia a través de la lente de género

El objetivo es explorar diferencias entre las respuestas de los y las adolescentes, ya sea como víctimas o como practicantes de, en un estudio portugués con 1683 niños y 1837 niñas de $\operatorname{los} 6^{\circ}, 8^{\circ}$ y $11^{\circ}$ grados de 23 escuelas. Las niñas mostraron mayor tendencia a ser víctimas y los chicos para ser agresores. En ambos sexos se observó una correlación positiva entre ser víctima y ser perpetrador/a. La ruptura de la amistad y el rechazo social fueron las razones mencionadas con mayor frecuencia por las niñas para explicar sus experiencias de victimización o de la práctica de, y fueron más capaces que los varones de indicar las emociones y motivos involucrados. Se discuten las implicaciones teniendo en cuenta la socialización de género y las características de esta etapa de desarrollo.

Palabras clave: cyberbullying, las diferencias entre niños y niñas, adolescencia, estilos de interacción entre los jóvenes, estereotipos de género.

\section{Introduction}

Despite the undeniable educational benefits of the use of information and communication technologies (ICT) in formal and non-formal contexts, which has increased significantly in recent years, particularly among young people (Coyette et al. 2015), the potential risks and damage to the personal and social lives of the so-called 'native digitals' (Prensky 2001) have not yet been clearly identified. Moreover, the fact that young people have grown up in a digital age leads them to perceive the virtual world in a different way to adults (Paul, Smith and Blumberg 2012), which may create difficulties for parents and professionals involved in designing intervention and prevention strategies to help them anticipate the consequences of their acts and use technology in a positive way in their relationships with others.

A broad range of behaviours can be considered cyberbullying and authors have not yet reached a consensus on the best typology to follow (see Willard 2005; 2007), which has led to some difficulties in operationalizing cyberbullying and the consequent problems of comparability across studies. The complexity of cyberbullying behaviours and the range of technological devices available in recent years have also given rise to a general categorization divided «into two distinct types: the use of computer technology or cell phones to bully others in the real world; and the use of cyberspace to bully others in the virtual world» (Aoyama and Talbert 2010, 185). In this paper, we adopt the definition proposed by Robert Tokunaga, who characterizes cyberbullying as «any behaviour performed through electronic or digital media by individuals or groups that repeatedly communicates hostile or aggressive messages intended to inflict harm or discomfort on others» $(2010,278)$.

In research into direct and covert forms of bullying - referred to here as traditional bullying - the characteristics of aggressors and victims have not been 
empirically validated in relation to cyberbullying. Recently, Susan Hymel and Shelley Swearer (2015) have suggested that although social and verbal bullying are the most common forms of traditional (face-to-face and covert) bullying experienced by pupils, cyberbullying should also be a major concern.

For researchers such as Marilyn Campbell (2005), cyberbullying can be potentially more harmful for victims than traditional bullying, since factors such as the anonymity of the aggressors, duration of the occurrence ( 24 hours / 7days) and size of the audience (Slonje and Smith 2008) may produce more long-lasting and unpredictable effects. Moreover, as Sheri Bauman (2011) emphasised, the anonymity of the bully can generate a growing sense of widespread distrust in victims that can affect the quality of their relationships with friends and relatives. The expected superiority of the aggressor in comparison to the victim, either in terms of physical stature, age or social popularity, commonly seen as facilitators of traditional bullying (Turan et al. 2011), may be replaced in cyberbullying by the adolescent's mastery of technologies (Matos et al. 2011) associated with the fact that aggression in the digital world can occur at any time or place, simply for entertainment or for revenge (Willard 2005).

According to Robert Tokunaga (2010), approximately $20 \%$ to $40 \%$ of young people have been victims of cyberbullying at least once in their lifetime. Certain aspects, such as the amount of time spent on the internet, the sharing of information with strangers, including photos and chatting to strangers via electronic media, are risk factors associated with the possibility of becoming a victim of cyberbullying (Turan et al. 2011).

Differences between males and females do not emerge consistently across studies when boys and girls are compared in terms of cyberbullying practices ( $\mathrm{Li}$ 2006; Ang and Goh 2010; Tokunaga 2010). Although boys tend to be much more involved in traditional (offline) bullying practices, mainly as aggressors (Hymel and Swearer 2015), this trend is not always detected in studies on cyberbullying. Some studies have already found no differences between boys and girls involved in these practices, when adolescents are analysed either as aggressors or victims (Hinduja and Patchin 2008). Other studies found that more girls tend to be victims of cyberbullying, despite the lack of differences between males and females in the tendency to cyberbully others (e.g., Smith et al. 2008). In line with traditional bullying practices, other research ( $\mathrm{Li} 2006$ ) has found that boys are more likely to be both cyberbullies and cybervictims than girls, but adolescent girls are more likely than their male peers to tell adults about their experiences of victimization. When subtypes of cyberbullying practices are analysed separately, there is evidence that boys are more likely to be aggressors than girls in relation to certain acts such as harassment and persecution, whereas girls are more prone to engage in social exclusion, although in the majority of subtypes there are no differences between young female and male cyberaggressors (Buelga and Pons 2012).

Data emerging mainly from gender studies and developmental psychology has shown that adolescent boys and girls tend to exhibit differences in social 
behaviour that are already marked in earlier stages of life, but become more prominent after puberty, with ongoing cognitive and emotional maturation and the emergence of critical thinking (Sprinthall and Collins 2011). By the time it comes to establishing friendship bonds and closer relations with others, both sexes are more able to genuinely think about a friend's worries and wellbeing and share their concerns and fears, and research has revealed differences between adolescent boys and girls in terms of the way in which this support is expressed and accepted amongst friends (Beal 1994).

Following the seminal work of Eleanor Maccoby (1998a; 1998b; 2000), we know that, from preschool years to adolescence, girls tend to form friendships with same-sex peers, sharing more secrets and confessing their weaknesses or fears to other young females than boys do with their male friends; boys tend to cement their relationships more in terms of shared activities and common interests involving same-age male friends, mostly in larger and less self-disclosing groups. In line with these characteristics, it has been found that girls and boys tend to have the same frequency of internet use, but for different main purposes (Willard 2007). This makes it equally likely for them to engage in cyberbullying, but in different ways (Aoyama and Talbert 2010). In fact, research has already found that boys use computers mainly for searching and playing games, whereas the favourite online activity for girls is socializing with others (Turan et al. 2011).

Adolescence is a critical period for shaping identity and seeking peer group acceptance, in which both sexes undergo a series of changes in interpersonal understanding which have undeniable influences on their social behaviour (Sprinthall and Collins 2011), including the internalization of norms related to socially constructed standards of femininity and masculinity which give rise to a gender hierarchy that tends to prescribe individual behaviours (Amâncio 1994; Saavedra 2005).

As Philip Rodkin, Dorothy Espelage and Laura Hanish (2015) have suggested in their analyses of traditional bullying, we believe that a more comprehensive and relational study of cyberbullying behaviours during adolescence should include an analysis of socialization contexts from the perspective of gender (Scott 1986), using Sandra Bem's (1994) 'gender lenses', given that the aforementioned differences in social behaviour in both sexes are reinforced by the influence of gender stereotypes that exert control over adolescent behaviour (Vieira et al. 2013).

Due to the fact that they tend to share more private information with other (girl)friends, female adolescents are more vulnerable, for example, to becoming a target for rumour and gossip by former friends and the breakup of relations between peers seems to be a more intensely emotional process for girls than boys (Maccobby 1998b). On the other hand, based on the learned power of hegemonic masculinity, considered not as a trait (essentialist perspective), but as a set of messages learned and constructed in specific social contexts (Connell and Messerschmidt 2005) about what is supposed 'to be real a man', after puberty 
boys tend to be afraid of others doubting their maleness, for instance, and the use of homophobic language or other forms of gender-based harassment are not uncommon among youths as a means of enforcing the traditional norms of masculinity (Carrito and Araújo 2013; Birkett and Espelage 2015).

Taking the evidence from previous studies into consideration, the purpose of this paper is to explore differences between males and females in young people's responses to how they have experienced or dealt with the negative use of communication technologies, focussing on those who stated they had been cybervictims or cyberaggressors. The responses of the adolescent girls and boys are tentatively interpreted within the framework of the gender social order and the relational nature of cyberbullying practices, which may also occur as a result of attempts by adolescents to expand their social world without always deploying mature critical thinking to prevent and avoid the negative effects of mishandling communication technologies.

\section{Methodology}

\section{Participants}

The convenience sample in this study was composed of 3525 pupils from 23 schools and groups of schools located in 9 of the 18 districts in Portugal. Pupils from the $6^{\text {th }}, 8^{\text {th }}$ and $11^{\text {th }}$ years were selected for the sample, in order to represent the period of adolescence in which research suggests cyberbullying is most prevalent (see Matos et al. 2011). Female adolescents comprised 52.1\% $(\mathrm{n}=1837)$ of the total sample and male adolescents $47.7 \%(n=1683)$. There were 5 missing values.

In terms of age, the sample as a whole ranged from 10 to 19 years old (mean age $=13.6, S D=2.3$ ). The very few cases of older students were excluded. The subjects were very evenly distributed across the three school years: pupils from the $6^{\text {th }}$ year accounted for $31.92 \%$ of the sample, pupils from the $8^{\text {th }}$ year were $34.53 \%$ and pupils from the $11^{\text {th }}$ year accounted for $33.25 \%$. Eleven students did not answer this question.

\section{Instrument}

The Diagnostic Questionnaire on Cyberbullying (DQC) is a self-response questionnaire developed by the research team, which is divided into four sections mainly consisting of multiple-choice questions. An explanation about cyberbullying was provided at the beginning in order to improve the validity of the pupils' responses. After the initial socio-demographic questions, the first section aimed at gathering data on the use of ICT by adolescents, both in terms of frequency of use and the technological devices available to them. The second part was 
designed to analyse situations of cybervictimisation and included close-ended questions about the equipment used by aggressors, the identity of the bullies, types of acts, feelings about being cyberbullied and the victim's perceptions of the motives underlying the problem. The third part covered cyberaggression and also included close-ended items designed to explore types of cyberaggression, equipment used, reasons for the acts, the aggressors' perceptions of their victims' feelings and self-judgments of their own conduct as cyberbullies. The aim of the final part was to find out who the pupils thought victims of cyberbullying should go to for help. The questionnaire ended with an open-ended question that invited pupils to share their comments, suggestions and stories of cyberbullying.

\section{Procedure}

Following approval of the study by the Portuguese Ministry of Education and Science and the permissions given by school boards and parents/guardians of the pupils, the questionnaire was administered by teachers in the classroom during the first semester of 2012, with assurances of confidentiality and anonymity which respected all the ethical criteria for scientific data collection involving minors.

\section{Results}

The data is presented by comparing the answers of boys and girls, both as cybervictims or cyberaggressors. It begins with the overall prevalence of these 'cyber roles' within the total sample $(n=3525)$, followed by a separate analysis in the male and female subgroups. Correlations between the stated frequency of internet use by both sexes and other variables are also presented, together with the associations between being a cybervictim as well as a cyberperpetrator in the year prior to data collection. Finally, the data is described separately for individuals who said they had been victims of cyberacts and those who admitted practising cyberbullying during the same period.

\section{Prevalence of cyberbullying by sex and correlations with internet use}

The prevalence of cyberbullying found in our sample (Table 1) was $7.6 \%$ $(n=267)$ for victims who stated they had been cyberbullied during the previous year. In comparing the percentages for victims of both sexes, it can be seen that the rate for being cyberbullied was higher for females $(9.1 \%)$ than males $(6 \%),\left[\chi^{2}(1)=\right.$ $12.28 ; p<0.001]$. When pupils were asked if they had been cyberaggressors during the previous year, $3.9 \%(n=138)$ answered positively, with the rate of affirmative responses higher in males $(4.9 \%)$ than females $(3.1 \%),\left[\chi^{2}(1)=7.76 ; p<0.01\right]$. 
Table 1

Prevalence of cyberbullying by sex: victims and aggressors

\begin{tabular}{cc}
\hline Victims & Aggressors \\
\hline $\mathrm{n}=267(6.7 \%)$ & $\mathrm{n}=138(3.9 \%)$ \\
100 male victims $(6.0 \%)$ & 82 male aggressors $(4.9 \%)$ \\
167 female victims $(9.1 \%)$ & 56 female aggressors $(3.1 \%)$ \\
{$\left[X^{2}(1)=12.28 ; \mathrm{p}<0.001\right]$} & {$\left[\mathrm{X}^{2}(1)=7.76 ; \mathrm{p}<0.01\right]$} \\
More girls tend to be victims than boys & More boys tend to be aggressors than girls \\
\hline
\end{tabular}

The correlations between frequency of internet use, age, school year and likelihood of becoming a cybervictim or a cyberaggressor were also calculated separately for adolescent boys and girls (Table 2). In the male sample, frequency of internet use correlates positively with the propensity to cyberbully others $(\mathrm{r}=$ 0.077; $p<0.01$ ) and the boys who reported having been the targets of cyberacts in the previous twelve months tended to answer positively to the question of whether they had perpetrated similar acts during the same period $(\mathrm{r}=0.313 ; p<$ 0.01). In this study, internet use is not associated with the propensity of boys to become cybervictims $(\mathrm{r}=0.017 ; p>0.05)$. Age $(\mathrm{r}=0.300 ; p<0.01)$ and school year $($ rho $=0.366 ; p<0.01)$ correlated positively with frequency of internet use and consequently with cyberbullying $(\mathrm{r}=0.135, p<0.01$ for age; rho $=0.122, p<0.01$ for school year) and suffering from cyberbehaviours $(\mathrm{r}=0.055, p<0.05$ for age; rho $=0.063, p<0.05$ for school year).

Table 2

Correlations between frequency of internet use, age, school year and cyberbullying practices, by sex of the respondents

\begin{tabular}{lccccc}
\hline \multicolumn{5}{c}{ Adolescent boys (n=1683) } \\
\hline \multicolumn{1}{c}{ Variables } & $\begin{array}{c}\text { Frequency of } \\
\text { internet use }\end{array}$ & $\begin{array}{c}\text { Being a } \\
\text { cybervictim }\end{array}$ & $\begin{array}{c}\text { Being a } \\
\text { cyberaggressor }\end{array}$ & Age & School year ${ }^{(1)}$ \\
\hline Frequency of internet use & - & & & \\
Being a cybervictim & 0.017 & - & - & \\
Being a cyberaggressor & $0.077^{* *}$ & $0.313^{* *}$ & $0.135^{* *}$ & - & \\
Age & $0.300^{* *}$ & $0.055^{*}$ & $0.122^{* *}$ & $0.906^{* *}$ & - \\
School year ${ }^{(1)}$ & $0.366^{* *}$ & $0.063^{*}$ & & \\
\hline \multicolumn{5}{c}{ Adolescent girls (n=1837) } & \\
\hline Frequency of internet use & - & & & \\
Being a cybervictim & $0.073^{* *}$ & - & - & - \\
Being a cyberaggressor & 0.035 & $0.190^{* *}$ & - & - \\
Age & $0.329^{* *}$ & 0.043 & $0.077^{* *}$ & - \\
School year ${ }^{(1)}$ & $0.381^{* *}$ & $0.083^{* *}$ & $0.108^{* *}$ & $0.927^{* *}$ & - \\
\hline
\end{tabular}

(1) Nonparametric correlations (Spearman's rho); ${ }^{*}$ Correlation is significant at $p<0.05$ (2-tailed); ${ }^{* *}$ Correlation is significant at $p<0.01$ (2-tailed). 
Considering the results for adolescent girls using the same variables, frequency of internet use correlated positively with the likelihood of being cyberbullied $(r=0.073 ; p<0.01)$, but not with becoming cyberaggressors $(r=0.035 ; p>$ 0.05). Like the boys, the female adolescents who stated they had suffered from cyberacts during the year prior to data collection tended to respond positively to the question of whether they had also been involved in cyberaggression directed towards others $(\mathrm{r}=0.190 ; p<0.01)$. Frequency of internet use seemed to increase with age $(r=0.329 ; p<0.01)$ and this variable is positively related to the likelihood of girls becoming cyberaggressors $(\mathrm{r}=0.077 ; p<0.01)$, but not cybervictims $(\mathrm{r}=.043 ; p>0.05)$. School year correlated positively with frequency of internet use $(r=0.381 ; p<0.01)$ and the tendency of these girls to be either victims of acts of cyberbullying $(\mathrm{r}=0.083 ; p<0.01)$ or perpetrators $(\mathrm{r}=0.108 ; p<0.01)$.

\section{Specific data on self-reported cybervictimization}

The responses relating to the channels of communication through which victims experienced cyberaggression were very similar for both male and female adolescents. The most frequent method reported was via websites, including hi5 and Youtube, and social networks such as Facebook, which was the case for $51.9 \%$ of the girls and $43.8 \%$ of the boys. This was followed by cyberaggression via text messages (SMS), mentioned by $44.0 \%$ of the girls and $35.4 \%$ of the boys, and phone calls, which were cited by $34.0 \%$ of female adolescents and $31.2 \%$ of male adolescents. The percentages for other forms of communication, such as email, chats and instant messaging, were not significant. Nonparametric comparisons using the Pearson Chi-Square Test showed no differences between boys and girls in the means mentioned by both male and female victims, which may be explained by the fact that adolescents of both sexes may be equally proficient - either for positive and negative purposes — in their use of ICT.

Being male or female was shown to be related to the sex of the aggressors, whether the acts were perpetrated individually or in groups: $\left[\chi^{2}(6)=24.300\right.$; $p<0.001]$. In line with previous research into same-sex and cross-sex interactions in social life offline (Maccoby 1998a; 1998b), our results show that the boys were cyberbullied more by other adolescent males, both acting alone $(31.5 \%)$ or in groups $(15.2 \%)$, and girls were cyberbullied more by other adolescent girls, who seemed to act either alone $(21.3 \%)$ or in groups $(16.0 \%)$. However, it is also worth noting the percentage of girls that said their aggressor was a boy $(20 \%)$. A very high percentage of both sexes stated that they did not know who their aggressor was (29.3\% of the boys; $26.7 \%$ of the girls), a fact that may be related to the anonymity which characterizes cyberbullying, in contrast to traditional bullying.

An analysis of differences between males and females in cybervictimization by behaviour type revealed no significant results in the majority of cyberbullying subtypes, although girls scored higher than boys on two items: 'Spreading rumours' $[F(1,242)=18.981 ; p<0.001]$ and 'Revealing secrets or information 
about private life' $[\mathrm{F}(1,233)=4.592 ; p=0.033]$. This is not a surprising result given that girls tend to share more intimate information, including their secrets and emotions, with their same-sex adolescent friends than boys (Maccoby 2000; Shields 2000) and are therefore probably more vulnerable to this kind of aggression involving the misuse of ICT.

Self-reported feelings associated with being a victim of cyberaggression were also analysed in the questionnaire. After being targeted by cyberacts, boys and girls reported six feelings differently out of the sixteen options available to them in the questionnaire. Female adolescents described feelings such as sadness $\left[\chi^{2}(1)=\right.$ 19.153; $p<0.01]$, fear $\left[\chi^{2}(1)=6.848 ; p=0.009\right]$, terror $\left[\chi^{2}(1)=4.192 ; p=0.041\right]$, insecurity $\left[\chi^{2}(1)=7.570 ; p=0.006\right]$, and loneliness and vulnerability (helplessness) $\left[\chi^{2}(1)=4.258 ; p=0.028\right]$ more than boys. Male adolescents only outscored females in self-reporting a desire for revenge $\left[\chi^{2}(1)=6.497 ; p=0.011\right]$. There were no differences in self-reported feelings such as despair, anger, humiliation, indifference, injustice, feeling like running away, guilt, confusion and feeling lost.

With regard to the victims' perceptions of the perpetrators' motives for cyberaggression, only two differences between males and females were found, which are consistent with scientific literature on gender and emotions (Fischer 2000). In comparison to boys who were cybervictims, girls who had suffered cyberbullying tended to emphasize reasons such as the breakdown of friendships $\left[\chi^{2}(1)=4.129 ; p=0.042\right]$ and rejection of their friends ('for not liking me') $\left[\chi^{2}(1)=7.273 ; p=0.007\right]$. There were no differences between males and females in the victims' attribution of motives to aggressors, in the sense that both boys and girls who had suffered cyberbullying considered the same possible motives, such as lack of respect, envy, difference of opinion, the need to have fun, being upset, having nothing to do, for fun, jealousy, revenge and immaturity.

Table 3

Differences between boys and girls in victim response behaviour to cyberaggression

\begin{tabular}{lccrr}
\hline $\begin{array}{c}\text { Victim response behaviour } \\
\text { to cyberaggression }\end{array}$ & $\begin{array}{c}\text { \% of male } \\
\text { victims }\end{array}$ & $\begin{array}{c}\text { \% of female } \\
\text { victims }\end{array}$ & $\boldsymbol{X}^{\mathbf{2}(\mathbf{1})}$ & $\boldsymbol{p}$ \\
\hline I told my parents & 14.6 & 35.2 & 12.827 & $<0.001$ \\
I cried & 11.5 & 43.2 & 28.215 & $<0.001$ \\
I told my friends & 28.1 & 42.6 & 5.400 & 0.020 \\
I physically attacked the person & 11.5 & 1.2 & 13.168 & $<0.001$ \\
I started to be more careful & 20.8 & 35.8 & 64.040 & 0.011 \\
I told my teachers & 4.2 & 11.7 & 4.245 & 0.039 \\
\hline
\end{tabular}

As a response to cyberaggression (see Table 3), the male adolescents in our sample reported using physical strength to solve the problem by attacking the person who had cyberbullied them $\left[\chi^{2}(1)=13.168 ; p<0.001\right]$ more than the females. The girls tried to find more support than the boys by talking about the 
problem with adults, such as parents $\left[\chi^{2}(1)=12.827 ; p<0.001\right]$ and teachers $\left[\chi^{2}(1)=4.245 ; p=0.039\right]$, or with friends $\left[\chi^{2}(1)=5.40 ; p=0.020\right]$. Adolescent girls also admitted crying more than boys $\left[\chi^{2}(1)=28.215 ; p<0.001\right]$, and being more careful about the use of ICT after cyberbullying $\left[\chi^{2}(1)=64.04 ; p=0.011\right]$.

\section{Specific data on self-reported cyberaggression}

The answers given by aggressors involving the same variables considered for victims will now be analysed. The content of the items in the third part of the questionnaire (have you cyberbullied others in the past twelve months?) was almost the same as in the second part, except that the respondents were now the cyberaggressors. There were no differences between the answers given by adolescent boys and girls concerning the means of communication used to cyberbully others, with the exception of e-mails, which was the only channel reported more by boys than by girls $\left[\chi^{2}(1)=7.835 ; p=0.050\right]$.

In relation to the identification of victims by cyberaggressors, results showed that there was a relationship between the sex of the perpetrator and the sex of the victim. As with the victims' answers, the data again revealed mainly same-sex dyads: more than half of the boys (52.9\%) reported engaging in cyberaggression mostly directed towards male adolescents and more than half of the girls $(54.5 \%)$ stated that their targets were other adolescent females.

Comparing the responses of both sexes concerning the type of behaviour they used to harm others via ICT, significant differences could only be found in four of the twelve possibilities mentioned and in all of them boys scored higher than girls. More male than female adolescents stated that they had sent offensive, insulting and defamatory messages $[\mathrm{F}(1,120)=4.048 ; p=0.046]$, taken photos without permission to cause harm $[\mathrm{F}(1,119)=3.971 ; p=0.049]$, made and / or circulated videos for the same purpose $[\mathrm{F}(1,119)=4.489 ; p=0.036]$, and caused harm through messages, photos and/or videos of a sexual nature $[\mathrm{F}(1,118)=$ 5.521; $p=0.020]$. Regarding the other types of cyberbullying considered in the questionnaire, both sexes revealed a tendency to use the same strategies to inflict harm on their victims.

Only three differences between boys and girls emerged in the aggressors' perceptions of the feelings of victims of cyberaggression, with the scores of girls ranking higher than those of boys. More female than male adolescents thought that their victims felt a desire for revenge $\left[\chi^{2}(1)=3.839 ; p=0.050\right]$, insecurity $\left[\chi^{2}(1)=5.015 ; p=0.025\right]$, and confusion and a sense of being lost $\left[\chi^{2}(1)=4.242 ; p\right.$ $=0.039]$. With regard to other types of feelings such as humiliation, injustice, anger and guilt, the perceptions of both sexes were similar.

Concerning the motivations that lead to cyberaggression (Table 4), more male than female perpetrators cited being upset with the victim $\left[\chi^{2}(1)=5.552 ; p=0.018\right]$. For females, motives such as the breakdown of friendships $\left[\chi^{2}(1)=3.945 ; p=0.047\right]$ and not liking the victim $\left[\chi^{2}(1)=5.001 ; p=0.025\right]$ were statistically more reported 
Table 4

Differences between boys and girls regarding motives of cyberaggressors

\begin{tabular}{lcccc}
\hline \multicolumn{1}{c}{ Self-reported motives of perpetrators } & $\begin{array}{c}\% \text { of male } \\
\text { aggressors }\end{array}$ & $\begin{array}{c}\text { \% of female } \\
\text { aggressors }\end{array}$ & $\boldsymbol{X}^{\mathbf{2}(\mathbf{1})}$ & $\boldsymbol{p}$ \\
\hline Being upset & 22.7 & 7.3 & 5.552 & 0.018 \\
Breakdown of friendships & 12.0 & 25.5 & 3.945 & 0.047 \\
Not liking him/her & 16.0 & 32.7 & 5.001 & 0.025 \\
\hline
\end{tabular}

than in the group of adolescent boys. Other internal driving forces such as jealousy, a sense of superiority, the need to have fun, and intolerance of difference (appearance, opinions, culture) were mentioned equally by both sexes.

Resembling an exercise in self-evaluation, the perpetrators also answered a set of questions about their feelings after cyberbullying. Both male and female adolescent perpetrators of cyberbullying showed a propensity to identify the same feelings after being aggressors, but the girls scored significantly higher than boys on sentiments such as relief $\left[\chi^{2}(1)=6.142 ; p=0.013\right]$, insecurity $\left[\chi^{2}(1)=\right.$ 4.188; $p=0.041]$ and confusion and vulnerability (feeling lost) $\left[\chi^{2}(1)=5.628 ; p=\right.$ $0.018]$. The boys may have been more ashamed to admit feeling distress as a consequence of their acts than the girls, although the task of recovering hidden and disturbing memories may not been easy for either sex.

\section{Discussion}

The results of our project showed that more adolescent girls were victims of cyberagression and more boys were perpetrators than girls. In addition, frequency of internet use correlated positively with the propensity to become a victim in the female sample and an aggressor in the male sample. In both groups, those who reported having been targeted by cyberaggression in the previous twelve months also tended to answer positively to the question of whether they had done the same to others during the same period. In our sample, being a cyberaggressor correlates positively with being a cybervictim for adolescent boys and girls. In both groups the reported frequency of internet use seemed to increase with age, and this variable correlated positively with the propensity to be either a victim or a perpetrator of cyberbullying amongst males, but not females. In the case of adolescent girls, the link to the possibility of becoming a cyberaggressor, but not a cybervictim increases as they get older.

There were no differences between the male and female subgroups in terms of the channels of communication used to engage in cyberacts against others. The only difference between males and females found for aggressors was the use of e-mail for cyberbullying, which was reported significantly more by boys than by girls. 
Consistent with this tendency to opt for same-sex social interactions in life offline during adolescence due to similar preferred styles of interaction, and for contact with other-sex peers mainly in mixed groups (Maccoby 1998a; 1998b; 2000), male victims tended to report more cyberbullying from boys than from girls, either committed alone or in groups. When asked about their role as aggressors, this same-sex bully-victim dyad prevailed: adolescent boys admitted cyberbullying boys more than girls, targeting lone individuals more than groups. The same was true for girls, who are mainly cyberbullied by same-sex peers, as well as being their aggressors. Cross-sex cyberaggression reported by victims was more common in boys than girls, and in this case the acts were mainly committed by one boy rather than a group of boys.

Differences in behaviour types involving ICT were found for girls in relation to acts such as sharing rumours and revealing secrets or information about their own private life. There were no differences between boys and girls in other types of cyber behaviour reported by victims. The answers given by cyberaggressors revealed differences between males and females in other types of behaviours, and in all cases boys scored higher than girls. The data showed that more male than female adolescents sent mainly offensive, insulting and defamatory messages, took photos without permission, made and/or circulated damaging videos, and spread messages, photos and/or videos of a sexual nature to harm their victims.

The feelings caused by cyberbullying that were self-reported more by girls than boys included sadness, fear, terror, insecurity, loneliness and vulnerability. More boys who were victims reported feeling a desire for revenge. With regard to image, in identifying the sentiments experienced by victims, the adolescent boys and girls who were cyberbullies scored similarly for the majority of feelings described, but the female respondents tended to highlight feelings such as the victim's desire for revenge more than the males, as well as insecurity, confusion and feeling lost.

Considering the gender socialization of emotions and gender stereotypes (Maccoby 1998a; Fischer 2000), the age of the participants should not be overlooked in interpreting this data, given that during adolescence incorporated views of maleness or femaleness influence both boys and girls when self-evaluating and self-describing their feelings and those of others and research has already shown that dysphoric self-conscious emotions tend to be viewed as 'unmanly', especially by boys (Brody 2000). Boys were probably more reluctant than girls to admit that they had experienced emotions socially considered more typically female, because their learned fears about not being considered real boys (Carrito and Araújo 2013) or because this exercise of recognizing emotions may conflict with the norms of masculinity they have incorporated in family context, school culture, peer group pressures, etc. (Connell and Messerschmidt 2005). Moreover, the possible influence of the social desirability should not be disregarded in the answers given by both sexes, due to the nature of the phenomenon under analysis. 
The motives for cyberbullying perceived by both the victim and the aggressor groups revealed two common sex differences, reflecting what tends to be valued more by girls than boys in their relationships with peers (Shields 2000): the breakdown of emotional ties in friendships and fears of social rejection by others. These findings are consistent with the characteristics of relationships established by adolescent females with their same-sex peers, which tend to foster self-disclosure with their friends and emotionally deeper interactions more than boys (Beal 1994). Adolescent boys who admitted to cyberaggression reported being upset with the victim to justify their behaviour more than girls.

Among the behaviours displayed by both sexes after suffering cyberbullying, crying and talking about the problem with others were reported more by girls than by boys, with the former being more likely to share the information with their parents, teachers and friends. More female than male adolescents reported being more careful with their use of ICT after experiencing cyberaggression. In line with the aforementioned finding that the boys cited a desire for revenge after victimization more than the girls, they also scored significantly higher on the statement that they had physically attacked the perpetrators in response to cyberacts. When the aggressors of both sexes were asked to report their feelings after engaging in cyberbullying, more female adolescents admitted sentiments such as relief, insecurity, confusion and vulnerability than boys. The male aggressors did not admit to a wider range of other types of feelings. According to our data, the feelings ranked highest by both sexes were satisfaction, pleasure and indifference to what had happened.

This research project involved a huge sample of Portuguese adolescents, but it is not representative of the whole country since it did not include data from young people living on the islands. Despite this limitation, the data provides important clues for reflection and intervention to combat the problem of cyberbullying. An additional limitation, common to other studies (Aoyama and Talbert 2010), concerns the operationalization of cyberbullying and the development of the questionnaire to collect data. Close-ended questions limit the adolescents' answers and may be subject to problems such as acquiescence or reluctance to admit to certain acts due to fear of being identified, possibly heightened by the fact that the data was collected in schools by teachers during classes. It is therefore possible that the true figures for cybervictimization and cyberaggression are greater in both the male and female groups than those which were self-reported.

\section{Conclusion}

Given that technological equipment is getting smaller, faster, more interactive, and more ubiquitous (Willard 2007), the number of users of technological devices is increasing (Coyette et al. 2015), especially among children and adoles- 
cents, ${ }^{2}$ and young people seems to be better prepared than parents and teachers to deal with its multiple potentials.

Due to the fact that adolescent boys and girls seem to be equally skilled in the use of ICT and the power differentials between victims and aggressors in cyberbullying seem to be more related to psychological variables (Angand Goh 2010) such as empathy, perspective-taking skills and positive attitudes in caring for others, programmes designed to prevent this problem should be based on a more relational, holistic and systemic approach, including the development of positive personality attributes and cognitive abilities. According to Wannes Heirman and Michel Walrave (2012), instead of insisting on control measures and policies to help families and schools, prevention and intervention strategies should be designed to reduce the perceived acceptability of cyberbullying among adolescents by converting impartial or positive attitudes towards these antisocial practices into negative evaluations.

The positive use of technology in individual and social life, together with the promotion of critical thinking skills that can help adolescents of both sexes make good, informed choices, understand the consequences of misusing the virtual world, and be aware of the relationship between online and offline interactions, are topics that should be included in educational initiatives designed to promote citizenship in both sexes from early childhood.

Future research on cyberbullying should also include parents' and teachers' perceptions and their ability to manage the ways in which the younger generations relate to ICT. In addition, greater use should be made of qualitative research strategies to listen to what adolescent boys and girls say about matters which researchers are unaware of and therefore cannot ask about using quantitative tools. The ethical issues involved in asking young people to disclose cyberbullying practices which may affect them, either as victims or perpetrators, may give rise to painful memories, and researchers should therefore develop further measures of such behaviours which cause the least possible harm to the respondents without compromising data accuracy.

\section{References}

Amâncio, Lígia. 1994. Masculino e feminino. A construção social da diferença. Porto: Edições Afrontamento.

Ang, Rebecca, and Dion H. Goh. 2010. «Cyberbullying Among Adolescents: The Role of

2 According to Eurostat data (Coyette et al. 2015), in 2014 Portugal was among the countries in Western Europe where the use of computers by young people was $25 \%$ higher than for the population as a whole (p. 195). Moreover, the highest proportion of internet users was found in the 16 to 19 age group and those with a higher level of formal educational (p. 196). For more details, see: http:/ / ec.europa.eu/eurostat/documents/3217494/6776245/KS-05-14-031-EN-N. pdf/18bee6f0-c181-457d-ba82-d77b314456b9 (accessed 5 August, 2016). 
Affective and Cognitive Empathy, and Gender». Child Psychiatry and Human Development 41(1): 387-397. DOI: https: / / doi.org/10.1007/s10578-010-0176-3

Aoyama, Ikuko, and Tony L. Talbert. 2010. «Cyberbullying Internationally Increasing: New Challenges in the Technology Generation». In Adolescent Online Social Communication and Behavior: Relationship Formation on the Internet, edited by Robert Zheng, Jason Burrow-Sanchez, and Clifford Drew, 183-201. Hershey, PA: Information Science Reference. DOI: https:/ / doi.org/10.4018/978-1-60566-926-7.ch012

Bauman, Sheri. 2011. Cyberbullying: What counselors need to know. Alexandria, VA: American Counseling Association.

Beal, Carole R. 1994. Boys and girls: the development of gender roles. New York: McGraw-Hill.

Bem, Sandra. 1994. The lenses of gender: transforming the debate on sexual inequality. New Haven, CT: Yale University Press.

Birkett, Michelle, and Dorothy L. Espelage. 2015. «Homophobic name-calling, peergroups, and masculinity: The socialization of homophobic behaviour in adolescents». Social Development 24(1): 184-205. DOI: https: / / doi.org/10.1111/ sode.12085

Brody, Leslie 2000. «The socialization of gender differences in emotional expression: Display rules, infant temperament, and differentiation». In Gender and Emotion. Psychological Perspectives, edited by Agneta H. Fischer, 24-47. Melbourne: Cambridge University Press. DOI: https:/ / doi.org/10.1017/CBO9780511628191.003

Buelga, Sofía, and Javier Pons. 2012. "Aggressions among adolescents through mobile phone and Internet». Psychosocial Intervention 21(1): 91-101. DOI: https://doi.org/ 10.5093 /in2012v21n1a2

Campbell, Marilyn. 2005. «Cyber bullying: An old problem in a new guise?» Australian Journal of Guidance and Counselling 15(1): 68-76. DOI: https:/ / doi.org/10.1375/ajgc.15.1.68

Carrito, Manuela, and Helena C. Araújo. 2013. «A 'palavra' aos jovens. A construção de masculinidades em contexto escolar». Educação, Sociedade e Culturas, 39: 139-158. Available at http: / / www.fpce.up.pt/ciie/ sites / default/files/09.Manuela_Helena.pdf

Connell, Raewyn W., and James W. Messerschmidt. 2005. «Hegemonic masculinity. Rethinking the concept». Gender \& Society 19(6): 829-859. DOI: https:/ / doi.org/ $10.1177 / 0891243205278639$

Coyette, Catherine, Isabelle Fiasse, Annika Johansson, Fabienne Montaigne, and Helene Strandell. 2015. Being young in Europe today. Eurostat Statistics Books 2015 edition. Luxembourg: European Union Publications Office. Available at: http: / / ec.europa.eu/ eurostat / documents / 3217494 / 6776245 / KS-05-14-031-EN-N.pdf / 18bee6f0-c181457d-ba82-d77b314456b9 [accessed 5.08.2016].

Fischer, Agneta H. (ed.) 2000. Gender and Emotion. Social and Psychological Perspectives. Melbourne: Cambridge University Press.

Heirman, Wannes, and Michel Walrave. 2012. "Predicting adolescent perpetration in cyberbullying: An application of the theory of planned behavior». Psicothema 24(4): 614-620. Available at http: / / www.psicothema.com/pdf/4062.pdf

Hinduja, Sameer, and Justin W. Patchin. 2008. «Cyberbullying: An exploratory analysis of factors related to offending and victimization». Deviant Behavior 29(2): 129-156. DOI: https:/ / doi.org/10.1080/01639620701457816

Hymel, Shelleyand, and Susan M. Swearer. 2015. «Four decades of research on school bullying». American Psychologist 70(4): 293-299. DOI: https: / / doi.org/10.1037 / a0038928

Li, Qing 2006. «Cyberbullying in schools: a research of gender differences». School Psychology International 27(2): 157-170. DOI: https: / / doi.org / 10.1177 / 0143034306064547

Maccoby, Eleanor E. 1998a. «Gender segregation: Childhood, adolescence, and adulthood. Gender and relationships: A developmental account». In Questions of gender. Perspec- 
tives and paradoxes, edited by Dina L. Anselmi and Anne L. Law, 294-305. New York: McGraw-Hill.

Maccoby, Eleanor E. 1998b. The two sexes. Growing up apart. Coming together. London: Harvard University Press.

Maccoby, Eleanor E. 2000. «Perspectives on gender development. International». Journal of Behavioral Development 24(4): 398-406. DOI: https:/ / doi.org/10.1080/016502500750037946

Matos, Armanda, Teresa Pessoa, João Amado, and Thomas Jäger. 2011. «Agir contra o cyberbullying. Manual de Formação». In Atas do Congresso Nacional Literacia, Media e Cidadania, edited by Sara Pereira, 183-195. Braga: Centro de Estudos de Comunicação e Sociedade.

Paul, Simone, Peter K. Smith, and Herbert H. Blumberg. 2012. «Investigating legal aspects of cyberbullying». Psicothema 24(4): 640-645. Available at http://www.psicothema. com/pdf/4066.pdf

Prensky, Marc. 2001. «Digital natives, digital immigrants». On the Horizon 9(5). DOI: https: / / doi.org/10.1108/10748120110424816

Rodkin, Philip C., Dorothy L. Espelage, and Laura D. Hanish. 2015. «A relational framework for understanding bullying: Developmental antecedents and outcomes». American Psychologist 70(4): 311-321. DOI: https: / / doi.org/10.1037 / a0038658

Saavedra, Luísa. 2005. Aprender a ser rapariga, aprender a ser rapaz. Teorias e Práticas da Escola. Coimbra: Almedina.

Scott, Joan W. 1986. «Gender: A useful category of historical analysis». The American Historical Review 91(5): 1053-1075. DOI: https:/ / doi.org/10.2307/1864376

Shields, Stephanie. 2000. «Thinking about gender, thinking about theory: Gender and emotional experience». In Gender and Emotion. Social Psychological Perspectives, edited by Agneta H. Fischer, 3-23. Melbourne: Cambridge University Press. DOI: https: / / doi.org/10.1017/CBO9780511628191.002

Slonje, Robert, and Peter Smith. 2008. «'Cyberbullying: Another main type of bullying?'». Scandinavian Journal of Psychology 49(2): 147-154. DOI: https: / / doi.org/10.1111/ j.1467-9450.2007.00611.x

Smith, Peter K., Jess Mahdavi, Manuel Carvalho, Sonja Fisher, Shanette Russell, and Neil Tippet. 2008. «Cyberbullying: Its nature and impact in secondary school pupils». Journal of Child Psychology and Psychiatry 49(4): 376-385. DOI: https: / doi.org/ 10.1111/j.1469-7610.2007.01846.x

Sprinthall, Norman A., and W. Andrews Collins. 2011. Psicologia do adolescente: uma abordagem desenvolvimentista ( th $^{\text {th }}$ ed.). Lisboa: Fundação Calouste Gulbenkian.

Tokunaga, Robert S. 2010. «'Following you home from school’: A critical review and synthesis of research on cyberbullying victimization'». Computers in Human Behavior 26(3): 277-287. DOI: https: / / doi.org/10.1016/j.chb.2009.11.014

Turan, Nursen, Oguz Polat, Mustafa Karapirli, Cem Uysal, and Seda Turan. 2011. «The new violence type of the era: Cyber bullying among university students. Violence among university students». Neurology, Psychiatry and Brain Research 17(1): 21-26. DOI: https: / / doi.org/10.1016/j.npbr.2011.02.005

Vieira, Cristina C. (coord.), Conceição Nogueira, and Teresa-Cláudia Tavares. 2013. «Theoretical Framework». In Education Guide. Gender and Citizenship 3rd Cycle, edited by Teresa Pinto (coord.), Conceição Nogueira, Cristina C. Vieira, Isabel Silva, Luísa Saavedra, Maria J. Silva, Paula Silva, Teresa-Cláudia Tavares and Vasco Prazeres, 13-46. Lisbon: Commission for Citizenship and Gender Equality. Available at: http: / / www.cig.gov.pt/pdf/2014/Education_Guide_3rd_Cicle.pdf [accessed 17.08.2015]. 
Willard, Nancy. 2005. Educator's Guide to Cyberbullying and Cyberthreats. Available at: http: / / education.ohio.gov / getattachment / Topics / Other-Resources / SchoolSafety / Safe-and-Supportive-Learning/ Anti-Harassment-Intimidation-and-BullyingResource/Educator-s-Guide-Cyber-Safety.pdf.aspx [accessed 13.07.2013].

Willard, Nancy. 2007. Cyberbullying and cyberthreats: Responding to the challenge of online social aggression, threats, and distress. Champaign, IL: Research Press.

Cristina C. Vieira. Associate Professor at the Faculty of Psychology and Educational Sciences of Coimbra University. Her research interests are related to gender, citizenship and education. Among other publications she coauthored the Educational Guides on Gender and Citizenship, published by Portuguese Commission for Citizenship and Gender Equality, for teachers' training in Portugal. She has been participating in national and international projects on gender issues.

Armanda Matos. Assistant Professor at the Faculty of Psychology and Educational Sciences of Coimbra University. Her main area of research is media education/ /media literacy, including themes such as media violence, cyberbullying, and the relationship between media/education/citizenship. She has participated in national and international projects such as BeCyberSafe and CyberTraining-4-Parents and has authored and co-authored several publications on these topics. armanda@fpce.uc.pt

João Amado. Associate Professor (Retired) from the Faculty of Psychology and Educational Sciences of Coimbra University. His recent publication Manual de Investigação Qualitativa em Educação (2013) was distinguished by the 2016 Award ICQI, as the best publication in Portuguese or Spanish related to the methodology of qualitative research. He created and coordinated distance learning courses for teachers about problems of violence, cyberbullying and conflicts in schools and he has many publications about such themes. joaoamado@fpce.uc.pt

Isabel Freire. Associate Professor at the Institute of Education, University of Lisbon, Portugal. Her main interests concerning research and teaching are related to curricula issues, teachers' training and ICT. She has several publications about promoting school discipline, preventing school violence and conflict mediation at school contexts. She is a member of a research centre about curricula and teachers' training. isafreire@ie.ulisboa.pt

Ana Margarida Veiga Simão. Associate Professor at the Faculty of Psychology, University of Lisbon in Portugal, where she teaches in the frame of Educational Psychology and Teacher Education degrees and coordinates the Master Degree and the Inter-University Doctoral Program on Educational Psychology. She is a researcher member of the Research Centre for Psychological Science. She has several articles, books and books chapters (http://www.peo.psicologia.ulisboa.pt/pt/projetos). amsimao@psicologia.ulisboa.pt.

Artigo recebido em 9 de outubro de 2016 e aceite para publicação em 20 de novembro de 2016. 